\title{
Impaired insulin action in newly diagnosed Type 1 (insulin-dependent) diabetes mellitus
}

\author{
A. Nankervis ${ }^{1,2}$, J.Proietto ${ }^{1,2}$, P. Aitken ${ }^{1}$ and F. Alford ${ }^{1,2}$ \\ 'Endocrine Unit and 2Department of Medicine, University of Melbourne, St. Vincent's Hospital, Fitzroy, Victoria, Australia
}

\begin{abstract}
Summary. Hepatic and peripheral insulin sensitivity were investigated in five newly diagnosed Type 1 (insulin-dependent) diabetic subjects before and after 1 week of twice daily insulin therapy. Eight weight-matched control subjects were also studied. Hepatic glucose production and glucose utilization were measured basally and during two sequential 2-h insulin (25 and $40 \mathrm{mU} \cdot \mathrm{kg}^{-1} \cdot \mathrm{h}^{-1}$ )/glucose infusion periods. In the untreated hyperglycaemic diabetic patients hepatic glucose production was $16.3 \pm 2.6,8.1 \pm 1.1$ and $3.6 \pm 2.8 \mu \mathrm{mol}$. $\mathrm{kg}^{-1} \cdot \mathrm{min}^{-1}$ respectively for each of the three periods (mean $\pm \mathrm{SEM}$ ), and fell with treatment to $12.5 \pm 1.4,0.5 \pm 0.5$ and $0.5 \pm 0.5 \mu \mathrm{mol} \cdot \mathrm{kg}^{-1} \cdot \mathrm{min}^{-1}$. Hepatic glucose production for normal subjects was $13.4 \pm 0.7,2.3 \pm 0.8$ and $<0.1 \mu \mathrm{mol}$. $\mathrm{kg}^{-1} \cdot \mathrm{min}^{-1}$. Glucose utilization was $12.7 \pm 1.4,18.2 \pm 0.7$ and $22.1 \pm 3.4 \mu \mathrm{mol} \cdot \mathrm{kg}^{-1} \cdot \mathrm{min}^{-1}$ before treatment in the diabetic subjects, and $11.8 \pm 1.7,20.9 \pm 3.3$ and $30.1 \pm 3.6$ after treatment. These values compare with those in the euglycaemic control subjects $(13.4 \pm 0.7,18.7 \pm 1.6$ and $36.3 \pm 2.7 \mu \mathrm{mol}$. $\mathrm{kg}^{-1} \cdot \min ^{-1}$ ). The pre-treatment metabolic clearance rate of glucose in all diabetic studies with insulin levels $>30 \mathrm{mU} / 1$ was $2.6 \pm 0.4$ and rose to $3.9 \pm 0.5 \mathrm{ml} \cdot \mathrm{kg}^{-1} \cdot \mathrm{min}^{-1}$ following
\end{abstract}

insulin therapy. This was significantly lower than in the control subjects $\left(6.7 \pm 0.8 \mathrm{ml} \cdot \mathrm{kg}^{-1} \cdot \mathrm{min}^{-1} ; p<0.005\right)$. Basal nonesterified fatty acid levels were high in the untreated, but normal in the treated diabetic subjects, and fell in response to insulin infusion. Basal $\beta$-hydroxybutyrate levels were high in both diabetic groups, but also fell in response to insulin infusion. Erythrocyte insulin receptor binding was normal in the untreated diabetic subjects, and was not changed by treatment. Therefore, treatment of newly diagnosed Type 1 diabetic subjects with insulin reverses the hepatic insensitivity to insulin. In contrast, treatment only partially improves peripheral glucose disposal. Since erythrocyte insulin receptor binding is normal, it is likely that a post-receptor defect in peripheral glucose metabolism exists in Type 1 diabetic patients despite insulin therapy and good diabetic control for a period of 1 week.

Key words: Heaptic glucose production, glucose utilization, metabolic clearance rate of glucose, insulin sensitivity, Type 1 diabetes.
Glucose intolerance in Type 1 (insulin-dependent) diabetes is caused by insulin deficiency. Complex metabolic changes, both at the insulin receptor and post-receptor level, result from this lack [1] and this might induce important changes in insulin action. Indeed, several studies, using a variety of methods to test insulin action in vivo, have demonstrated decreased insulin sensitivity in long-standing Type 1 diabetes [2-6]. More recently DeFronzo et al. [7] have shown both hepatic and peripheral insulin resistance in established Type 1 diabetic subjects, and Del Prato et al. [8] suggested that insulin insensitivity in established Type 1 diabetes is not restored to normal by improved metabolic control. However, Hall et al. [9] demonstrated that the hepatic glucose over-production in newly diagnosed Type 1 diabet- ic subjects was reversed with insulin therapy. Furthermore, in another study with newly diagnosed subjects, insulin sensitivity was described as normal [10]. These observations might indicate that the insulin resistance in Type 1 diabetes is an acquired defect, and might therefore be reversible in the early stages of the disease. However, the effects of insulin treatment on glucose turnover and insulin sensitivity in newly diagnosed untreated Type 1 diabetic subjects have not been studied previously. Therefore, the objective of this study was to determine whether a state of insulin insensitivity exists either in the liver or in peripheral tissues in newly diagnosed Type 1 diabetes, and further to determine the effects of insulin therapy on insulin action. Therefore hepatic glucose production and glucose utilization were 
Table 1. Clinical and basal biochemical data of diabetic and control subjects

\begin{tabular}{lllllll}
\hline $\begin{array}{l}\text { Diabetic } \\
\text { subjects }\end{array}$ & Sex & $\begin{array}{l}\text { Age } \\
\text { (years) }\end{array}$ & $\begin{array}{l}\text { Weight } \\
(\mathrm{kg})\end{array}$ & $\begin{array}{l}\text { Ponderal } \\
\text { index }\end{array}$ & $\begin{array}{l}\text { Fasting } \\
\text { plasma } \\
\text { glucose } \\
(\mathrm{mmol} / 1)\end{array}$ & $\begin{array}{l}\text { Fasting } \\
\text { plasma } \\
\text { insulin } \\
(\mathrm{mU} / 1)\end{array}$ \\
\hline 1 & $\mathrm{M}$ & 31 & 66 & 21.6 & 12.9 & 3 \\
2 & $\mathrm{~F}$ & 23 & 48 & 20.0 & 15.1 & 2 \\
3 & $\mathrm{~F}$ & 24 & 61 & 20.4 & 16.8 & 7 \\
4 & $\mathrm{M}$ & 26 & 75 & 26.0 & 13.3 & 6 \\
5 & $\mathrm{M}$ & 33 & 75 & 23.2 & 11.0 & 9 \\
$\begin{array}{l}\text { Mean } \pm \text { SEM } \\
\text { Control subjects }\end{array}$ & $27 \pm 2$ & $65 \pm 5$ & $22.2 \pm 1.1$ & $13.8 \pm 1.0$ & $5.4 \pm 1.3$ \\
$(n=8)$ & $39 \pm 6$ & $66 \pm 6$ & $23.0 \pm 1.1$ & $4.7 \pm 0.1$ & $9.4 \pm 0.9$ \\
\hline
\end{tabular}

Table 2. The coefficient of variation of plasma glucose levels of all groups studied

\begin{tabular}{llll}
\hline & \multicolumn{3}{l}{ Coefficient of variation of plasma glucose (\%) } \\
\cline { 2 - 4 } & Control group & $\begin{array}{l}\text { Pre-treatment } \\
\text { diabetic group }\end{array}$ & $\begin{array}{l}\text { Treated } \\
\text { diabetic group }\end{array}$ \\
\hline Basal & $2.1 \pm 0.2$ & $1.9 \pm 0.3$ & $3.2 \pm 1.2$ \\
$\begin{array}{l}\text { Low dose } \\
\left(25 \mathrm{mU} \cdot \mathrm{kg}^{-1} \cdot \mathrm{h}^{-1}\right)\end{array}$ & $3.6 \pm 0.7$ & $2.4 \pm 0.5$ & $3.1 \pm 0.7$ \\
High dose & $5.0 \pm 0.8$ & $5.7 \pm 0.1$ & $4.5 \pm 1.2$ \\
$\left(40 \mathrm{mU} \cdot \mathrm{kg}^{-1} \cdot \mathrm{h}^{-1}\right)$ & & & \\
\hline
\end{tabular}

Results expressed as mean \pm SEM

The mean co-efficient of variation was $3.45 \pm 0.4 \%$.

measured basally and during insulin infusions, at the time of diagnosis, and following 1 week of insulin treatment and good glycaemic control.

\section{Subjects and methods}

\section{Subjects}

Details of the subjects studied are shown in Table 1. Five newly diagnosed Type 1 diabetic subjects were studied before and 1 week after insulin treatment. All had symptoms of polyuria, polydipsia, lethargy and weight loss, but none were acutely ill or significantly dehydrated on admission. All had fasting hyperglycaemia and ketonuria. Following the initial glucose kinetic studies, all patients were placed on a diet with a carbohydrate content of 180-250 g daily and commenced on a combination of highly purified porcine neutral and Lente insulins (Novo Research Institute, Copenhagen, Denmark) administered twice daily. Fasting blood glucose levels were maintained in the range 4-6 $\mathrm{mmol} / \mathrm{l}$ and post-prandial levels were $4-10 \mathrm{mmol} / \mathrm{l}$.

Following 1 week of insulin therapy, metabolic studies were repeated. The last dose of insulin was given $24 \mathrm{~h}$ before the repeat studies. One repeat study was unable to be completed because of technical difficulties. Eight healthy, weight-matched control subjects with no family history of diabetes were also studied. Written informed consent was obtained from all subjects before their participation in the studies. The protocol was approved by the Ethics and Research Committee of St. Vincent's Hospital, Melbourne.

\section{Experimental procedures}

Subjects were studied after an overnight fast and a 60 -min period of recumbency. A $20-\mathrm{cm}$ intracath was placed, under local anaesthesia, into an antecubital vein, and solutions were infused through this catheter using a Minipuls II, 4 channel pump (Gilson, Villiers-le-Bel, France). Blood samples for estimation of total glucose, ${ }^{3} \mathrm{H}-3$-glucose, plasma insulin (IRI), plasma glucagon (IRG), C-peptide, $\beta$-hydroxybutyrate $(\beta-\mathrm{OHB})$ and non-esterified fatty acids (NEFA) were drawn at appropriate intervals from an indwelling catheter placed in a contralateral dorsal hand vein. As described previously [11] glucose turnover was measured using a primed constant infusion of ${ }^{3} \mathrm{H}-3$-glucose both basally and during the insulin infusions at two dose levels (25 and $\left.40 \mathrm{mU} \cdot \mathrm{kg}^{-1} \cdot \mathrm{h}^{-1}\right)$. The glucose pool was appropriately primed by giving an intravenous bolus dose of ${ }^{3} \mathrm{H}-3$-glucose according to the blood glucose level [11]. To prevent hypoglycaemia, 20\% glucose solution was infused simultaneously with the insulin infusions, at rates of 2 and $3 \mathrm{mg} \cdot \mathrm{kg}^{-1} \cdot \mathrm{min}^{-1}$ during the initial study and at 4 and $6 \mathrm{mg}$. $\mathrm{kg}^{-1} \cdot \mathrm{min}^{-1}$ during the repeat study. At the conclusion of each study, timed samples of the fluid delivered by the pumps were collected into weighed tubes to enable calculation of rates of infusion of tritiated glucose, unlabelled glucose and insulin. Urine was collected for the last $60 \mathrm{~min}$ of each period for the estimation of urinary glucose loss.

\section{Analytical procedures}

Blood for all hormone estimation was promptly centrifuged and the plasma stored at $-20^{\circ} \mathrm{C}$ until time of assay. Plasma samples for measurement of ${ }^{3} \mathrm{H}$-3-glucose specific activity were deproteinated with $\mathrm{Ba}(\mathrm{OH})_{2}-\mathrm{ZnSO}_{4}$ and total glucose and ${ }^{3} \mathrm{H}-3$-glucose were estimated in the supernatant $[12,13]$. Total glucose was measured with an analyser (Centrifichem C400, Union Carbide Corporation, New York), using a hexokinase method. Plasma IRI was estimated by radioimmunoassay, using dextrancharcoal separation of bound and free fractions [14]. Assay sensitivity for IRI was $1 \mathrm{mU} / 1$ with an interassay coefficient of variation at $22 \mathrm{mU} / 1$ of $8.4 \%$. Blood for IRG estimation was collected into chilled, heparinised tubes containing 5,000 KIU aprotinin (Trasylol, Bayer Pharmaceuticals, Botany, Australia). Plasma IRG was estimated by radioimmunoassay using dextran charcoal separation [15]. Assay sensitivity for IRG was $14 \mathrm{pg} / \mathrm{ml}$ with interassay coefficient of variation being $24 \%$ at $95 \mathrm{pg} / \mathrm{ml}$. NEFA was measured by a manual colorimetric modification of a method of Carruthers and Young [16] and ketone bodies were estimated spectrophotometrically by the method of Williamson et al. [17]. C-peptide was measured using the Novo Kit (Novo Research Institute, Copenhagen, Denmark) with antiserum M 1230. All samples were extracted with $25 \%$ polyethylene glycol before measurement of C-peptide activity [18]. Binding of ${ }^{125} \mathrm{I}$ insulin to human erythrocytes was measured using the method of Gambhir et al. [19].

\section{Calculations}

The rate of appearance of glucose $(\mathrm{Ra})$ at steady state was calculated from the formula $\mathrm{Ra}=\mathrm{F} / \mathrm{SA}$, where $\mathrm{F}=$ rate of infusion of tritiated glucose and $\mathrm{SA}=$ specific activity of the plasma tritiated glucose at steady state [20]. Steady state was defined as $<10 \%$ variation in the counts, specific activity, plasma glucose and IRI levels at the time of plateau. For all studies the mean coefficient of variation for plateau glucose levels and plateau counts were $3.5 \pm 0.4 \%$ and $6.1 \pm 0.1 \%$ respectively. A more detailed analysis of steady-state plasma glucose levels for all studies is shown in Table 2. In those studies in which the criteria for steady state were not met, the non-steady state equation of Steele, with a pool fraction of 0.65 , was used to calculate $R a$ [20]. In some studies, plateau glucose levels during the high dose insulin infusion period were lower than in the two preceding periods. Hepatic glucose production for the insulin/glucose infusion periods was calculated by subtracting the amount of unlabelled glucose infused from the calculated Ra. At steady state, $R a=$ rate of disappearance of glucose (Rd) and the rate of utilization of glucose was defined as the rate of disappearance of glucose minus the urinary glucose loss. In order to compare the groups with different glucose levels, the metabolic clearance rate of glucose was calculated as rate of utilization/plasma glucose concentration [21]. Because questions regarding the validity of 
Table 3. Biochemical and glucose kinetic data of diabetic and controll subjects

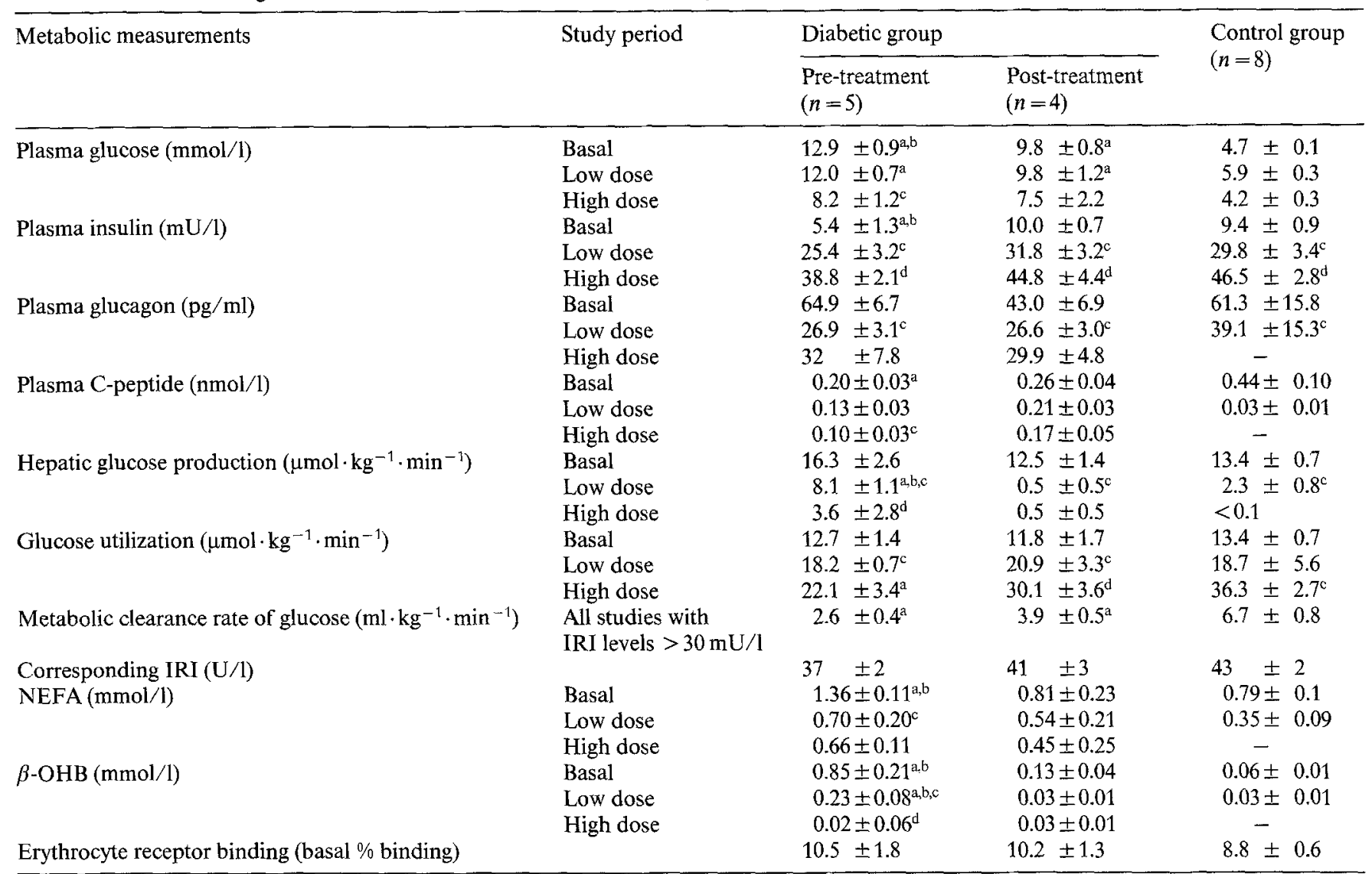

Results expressed as mean \pm SEM. ${ }^{\mathrm{a}} p<0.05$ when compared with the control group; ${ }^{\mathrm{b}} p<0.05$ when compared with the post-treatment group; ${ }^{\mathrm{c}} p<0.05$ when compared with basal levels; ${ }^{\mathrm{d}} p<0.05$ when compared with the low dose group

metabolic clearance rate of glucose have been raised [22, 23], metabolic clearance rate was calculated only when the plasma IRI was $>30 \mathrm{mU} / 1$ as discussed previously $[24,25]$. Statistical analyses were made using paired and unpaired Student's t-test and linear regression analyses. All data are expressed as mean \pm SEM.

\section{Results}

The biochemical details of the glucose turnover studies are given in Table 3. Basal plasma glucose levels were higher in the untreated diabetic group than in the treated group $(p<0.05)$, and both were higher than the euglycaemic control subjects $(p<0.001)$. Basal insulin levels were significantly lower in untreated diabetic subjects $(p<0.025)$ compared with treated diabetic or control subjects (Table 3 ). The plateau insulin levels rose significantly in each group during the low dose and then the high dose insulin infusion. The plateau insulin levels were similar for the three groups. As expected, basal C-peptide levels were low in the untreated diabetic group $(p<0.02)$, and C-peptide values rose in each diabetic individual following a period of insulin therapy. This increase was not significant for the group as a whole $(p>0.1)$. Although C-peptide levels were lower in the treated diabetic subjects than the control group, they just failed to reach statistical significance. Basal plasma IRG values were within the normal range for the three groups, and fell in response to low dose insulin.

\section{Hepatic glucose production}

Basal hepatic glucose production was higher in the untreated diabetic group than in the control group, but this just failed to reach statistical significance (Table 3 , Fig. 1). Basal hepatic glucose production in the treated diabetics was normal. Although blood glucose levels were raised in the diabetic groups, suboptimal suppression of hepatic glucose production occurred in response to low dose insulin in the untreated diabetic patients $(p<0.005)$. The treated diabetic group suppressed to the same extent as the control group. In both diabetic groups, hepatic glucose production was suppressed by high dose insulin. Thus, for the untreated diabetic group, basal hepatic glucose production was not suppressed, despite the accompanying basal hyperglycaemia. Further, hepatic glucose production was poorly suppressed when insulin levels were raised by the physiological insulin infusion, even in the presence of hyperglycaemia. Basal hepatic glucose production in the untreated diabetics strongly correlated with the fasting blood glucose levels $(r=0.86, p<0.05)$, but there was no 

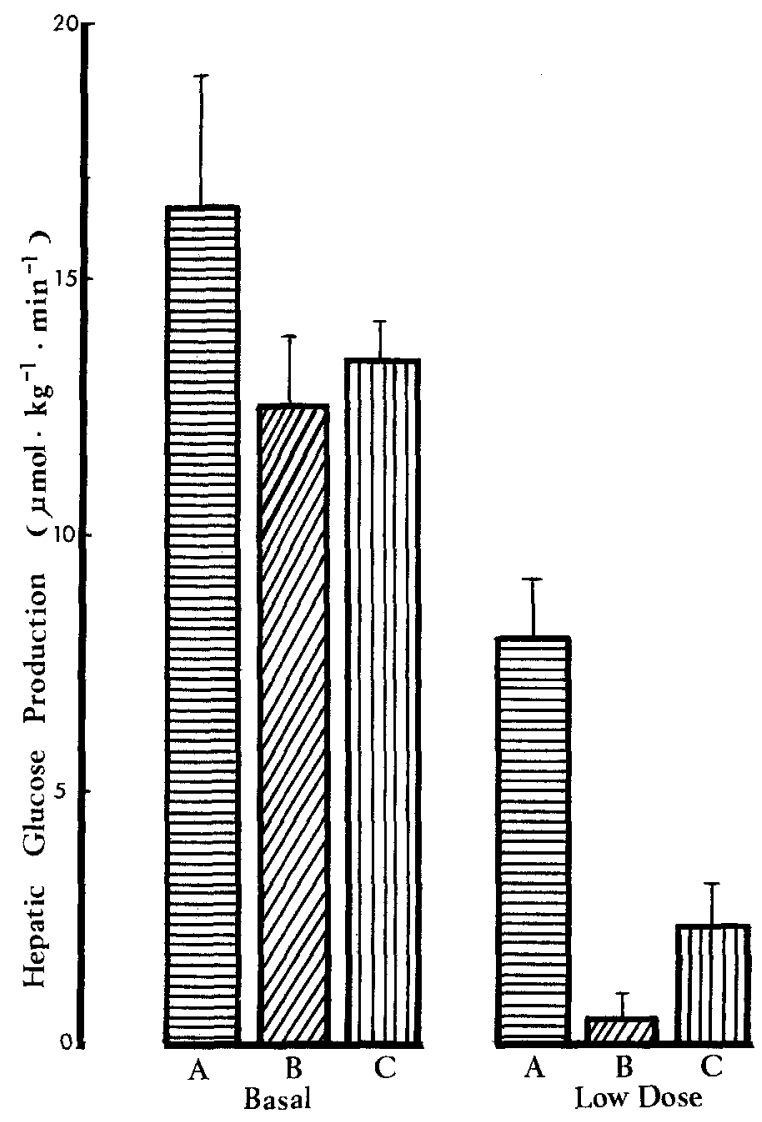

Fig. 1. Hepatic glucose output ( \pm SEM) of diabetic subjects before $(n=5, \mathrm{~A})$ and after $(n=4, \mathrm{~B})$ insulin therapy, and control subjects $(n=8, C)$. Values are shown for basal studies and the low dose insulin infusion period $\left(25 \mathrm{mU} \cdot \mathrm{kg}^{-1} \cdot \mathrm{h}^{-1}\right)$. Complete suppression occurred with high dose insulin $\left(40 \mathrm{mU} \cdot \mathrm{kg}^{-1} \cdot \mathrm{kg}^{-1}\right.$; not shown)

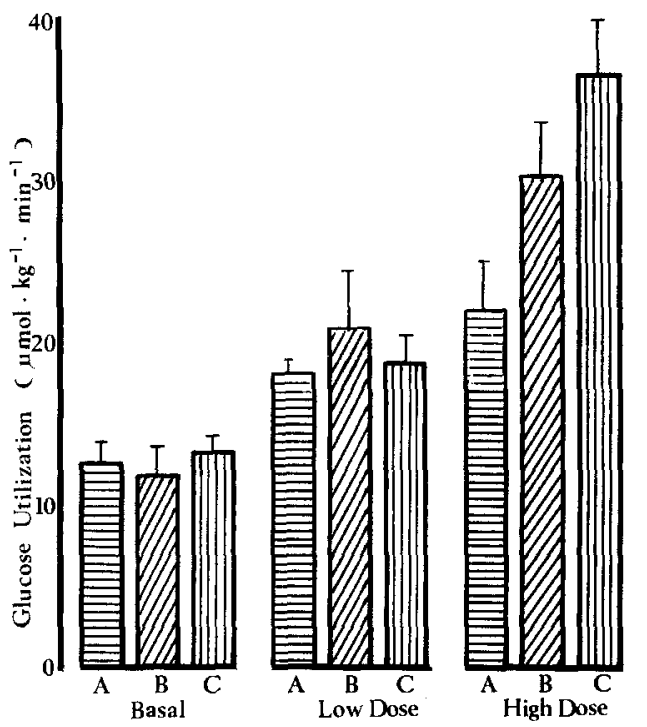

Figure 2. Glucose utilisation of diabetic subjects before $(n=5, \mathrm{~A})$ and after $(n=4$; B) insulin therapy and control subjects $(n=8 ; \mathrm{C})$. Values are shown for basal studies and each of the insulin infusion periods (low dose: $25 \mathrm{mU} \cdot \mathrm{kg}^{-1} \cdot \mathrm{h}^{-1}$; high dose: $40 \mathrm{mU} \cdot \mathrm{kg}^{-1} \cdot \mathrm{h}^{-1}$ )

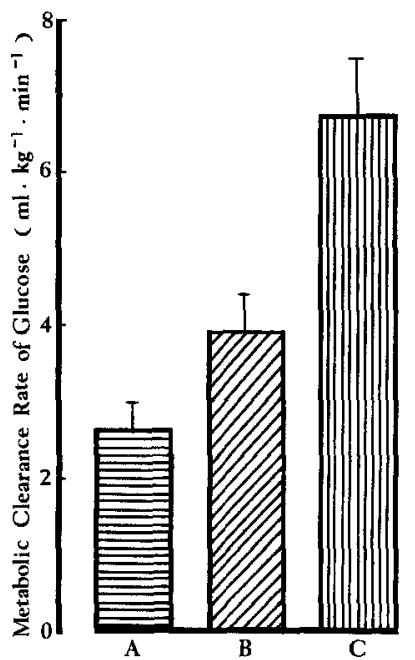

Figure 3. Metabolic clearance rate of glucose calculated for all studies with plasma IRI levels $>30 \mathrm{mU} / 1$ in diabetic subjects before $(n=7 ; \mathrm{A})$ and after $(n=8 ; \mathrm{B})$ insulin therapy, and control subjects $(n=12 ; \mathrm{C})$

correlation with the fasting IRI levels. In the treated diabetic group there was no correlation between hepatic glucose production and fasting glucose levels, but there was a negative correlation between hepatic glucose production and fasting IRI $(r=-0.82, p<0.05)$.

\section{Glucose utilization and metabolic clearance rate}

Basal glucose utilization was similar in each of the three experimental groups. However, this normal glucose utilization occurred in the presence of significant hyperglycaemia in the diabetic subjects. Glucose utilization rose equally in the three groups during the low dose insulin infusion (Fig. 2). During the high dose infusion glucose utilization failed to rise in the untreated diabetic subjects. In contrast, a marked rise occurred in the treated diabetic group $(p<0.05)$, and although this appeared to be less than the rise which occurred in the control subjects, the difference was not significant. Importantly, the glucose utilization of both diabetic groups was markedly less than that found in normal subjects $\left(114 \pm 7.0 \mu \mathrm{mol} \cdot \mathrm{kg}^{-1} \cdot \mathrm{min}^{-1}\right)$ at similar levels of hyperglycaemia $(10.2 \pm 0.7 \mathrm{mmol} / \mathrm{l})$ and hyperinsulinaemia $(50 \pm 19 \mathrm{mU} / \mathrm{l})$ in an earlier study [26]. Direct comparison of glucose utilization data is difficult in this study as both groups of diabetic patients were studied at hyperglycaemia, whilst the control subjects were at euglycaemia. Therefore, as an alternative way of examining overall glucose disposal, the metabolic clearance rate of glucose was calculated for all subjects with insulin levels of $>30 \mathrm{mU} / 1$ (Fig. 3). In the untreated diabetic subjects, profound impairment of glucose clearance existed and while this defect was improved by the week of insulin therapy with a $49 \%$ rise in glucose clearance, this was still strikingly less than the glucose clearance achieved in the normal group ( $p<0.001$, Fig. 3). 


\section{$N E F A$ and $\beta-O H B$}

Basal plasma NEFA values were higher in the untreated diabetic group than in either the treated diabetic $(p<0.05)$ or control $(p<0.005)$ subjects (Table 3$)$. Following insulin infusion, NEFA concentrations fell to similar levels in each group. Fasting $\beta$-OHB levels were markedly elevated in the untreated diabetic patients $(p>0.005)$ and although they had fallen considerably in the treated group, values remained high compared with the control subjects $(p>0,005) . \beta$-OHB levels were suppressed to a similar degree by high dose insulin in each group.

\section{Erythrocyte receptor insulin binding}

Insulin binding characteristics of the erythrocyte receptor were similar in all groups. The mean basal percentage binding of insulin to the receptor was $10.5 \pm 1.8 \%$ in the untreated diabetics, $10.0 \pm 1.3 \%$ in the treated diabetic subjects and $8.8 \pm 0.6 \%$ in the control group (Table 3). When the data were re-examined by Scatchard analysis to define the affinity of insulin for its receptor, no difference was found between the three groups.

\section{Discussion}

Insulin resistance in Type 2 (non-insulin-dependent) diabetes has been clearly documented [27], but the information regarding insulin sensitivity in Type 1 diabetes is sparse and conflicting [2-10]. Recent reports suggest insulin resistance is present in Type 1 diabetes $[4,6$, $7,9]$ and this resistance is not completely reversed by improved diabetic control [8]. However, these studies were in established Type 1 diabetes and the suggestion that newly diagnosed Type 1 diabetic subjects are not insulin resistant or that the insulin insensitivity can be reversed, would be consistent with the possibility that the insulin resistance is an acquired defect. This latter possibility was the subject of the present study.

Each group of subjects was studied at three different insulin levels, and this provided a means of examining the sensitivity of the liver to the suppressive effects of insulin. However, interpretation of hepatic production data must be guarded in view of the differences in plasma glucose levels between the groups studied. It would be expected that an elevated plasma glucose would in itself be exerting a suppressive effect on the liver. Therefore, while basal hepatic glucose production was not elevated in the untreated diabetic subjects, it was inappropriately high in the face of prevailing hyperglycaemia. In the presence of physiological increments of insulin and persistent hyperglycaemia, hepatic glucose production suppressed suboptimally. Thus, the liver appeared to be insensitive to the combined suppressive effects of both insulin and glucose. Basal hepatic glucose production correlated strongly with fasting blood glu- cose levels suggesting that hepatic glucose overproduction may be partially responsible for the fasting hyperglycaemia. There was no correlation between hepatic glucose production and IRG levels, and no significant correlation between fasting insulin levels and hepatic glucose production. Following treatment with insulin, the basal hepatic glucose production was lower, and suppressed to the same extent as the control group in response to low dose insulin. However, the fact that these treated subjects were also hyperglycaemic makes it impossible to determine whether the sensitivity of the liver to insulin had indeed reverted to normal, and that at euglycaemia, similar suppression with insulin would have occurred. Therefore, while elevated hepatic glucose production and hepatic insensitivity to insulin may be present in untreated or inadequately treated Type 1 diabetic patients, appropriate insulin therapy reverses the defect.

Another major finding in this study was the impairment in glucose utilization and clearance which is only partially reversed by insulin therapy. In untreated diabetic subjects basal glucose utilization was normal, and it is possible that normal basal glucose utilization is achieved by means of hepatic glucose overproduction and resulting hyperglycaemia [28]. However, in the treated diabetic group the hepatic defect has been reversed by therapy, and it seems likely that the fasting hyperglycaemia is related to some impairment in glucose clearance and peripheral insulin action. Again, it must be emphasised that this impairment in glucose utilization in the diabetic patients occurred in the presence of hyperglycaemia, and contrasts with the very high rates of glucose utilization previously noted in control subjects studied at comparable degrees of hyperglycaemia and hyperinsulinaemia [26]. An alternative approach to compare groups with different plasma glucose levels is to standardize glucose utilization data for differences in glucose levels. Therefore the metabolic clearance rate of glucose was calculated for all studies with insulin levels greater than $30 \mathrm{mU} / 1$ and plasma glucose levels less than $11 \mathrm{mmol} / 1[24,25,29,30]$. For this analysis, no assumptions concerning insulin versus non-insulin mediated glucose disposal were made, it merely being a measure of the efficiency of glucose removal. The defect in the efficiency of glucose clearance in diabetic subjects, both before and after treatment, was striking. Some improvement in clearance resulted from the week of insulin therapy, but still fell short of the glucose clearance seen in normal subjects at similar insulin levels. The length of time required for the observed improvement in clearance is unknown. It may have occurred acutely, or may have been a continuing process at the time of the second study, with the possibility of further improvement after a longer period of insulin therapy and good diabetic control. It is also possible that enhanced endogenous insulin secretion contributed to the improvement in glucose disposal, although fasting C-peptide levels were not higher in the treated compared with the 
untreated diabetic group. It is interesting to compare the partial but definite improvement in glucose utilization and glucose clearance obtained in these Type 1 diabetic subjects following the period of insulin therapy, with results obtained from similar studies on subjects with non-insulin-dependent diabetes. In the latter subjects, absolutely no improvement in glucose disposal resulted from a similar period of insulin treatment [11]. Interestingly, in a similar study by Scarlett et al., a significant improvement in glucose disposal occurred after 14 days of insulin therapy [31]. Clinically the insulin insensitivity in the Type 1 diabetic subjects is not likely to be an important factor in diabetic management, as it is in non-insulin-dependent diabetes.

There are several possible explanations for defective glucose clearance in our Type 1 patients. Basal $\beta$-OHB levels were elevated in both the treated and untreated diabetic subjects. However, in response to insulin infusion, the $\beta$-OHB levels fell normally in the treated diabetic group whilst the impairment in glucose utilization persisted. Further, there was no correlation between $\beta$ OHB levels and glucose utilization. Therefore, the possibility of ketone bodies being involved in the insulin resistance found in the treated diabetic subjects seems unlikely. It is known that fatty acids may inhibit insulin action [32] and were raised in the untreated diabetic subjects. However, following the week of insulin therapy, NEFA levels were normal and therefore are also an unlikely candidate for a major role in the aetiology of the insulin resistance. Cortisol and growth hormone levels were not elevated in the diabetic subjects before or after treatment. Although catecholamine levels were not measured in these studies, one might predict that they would have been normal in fit, well controlled, treated diabetic subjects [33]. Thus, it is unlikely that hormonal insulin antagonists played a significant role in the continuing insulin resistance. Finally, erythrocyte insulin receptor binding characteristics were similar in the treated and untreated diabetic and control subjects. While erythrocyte receptors do not necessarily reflect the behaviour of insulin receptors in insulin-sensitive tissues, in a number of studies insulin binding to receptors of a particular tissue reflected binding to other tissues [34, 35]. Further, we have found that monocyte binding in a similar group of Type 1 diabetic subjects gave identical results to the erythrocyte receptor data. Therefore it appears that the defect in glucose clearance is likely to be caused by a post-receptor abnormality. One possible explanation would be a depletion of glucose transport systems in the intracellular pool as has been found in the adipocyte of the streptozotocin insulin deficient rat model $[30,31,36,37]$.

Therefore, it is concluded that uncontrolled, newly diagnosed Type 1 diabetic subjects are characterised by inappropriately elevated basal hepatic glucose production and hepatic insulin insensitivity, and markedly impaired glucose clearance. Whilst the hepatic abnormality is completely reversed by 1 week of insulin therapy, the impairment in glucose disposal only partially resolves. This insulin resistance appears likely to be a post-receptor phenomenon, but the precise mechanism is unknown. The possibility that the defect could be reversed by a longer period of intensive insulin therapy deserves further study.

Acknowledgements. A. Nankervis and J. Prioetto are recipients of National Health and Medical Research Council Scholarships. We wish to thank the Biochemistry Department, St. Vincent's Hospital and M. Harewood for the expert technical assistance, and K. Dawson, J. Dew, M. Billings and J. Osborne for their assistance in the preparation of this paper. This work is supported by the NH \& MRC of Australia and the John Claude Kellion Foundation.

\section{References}

1. Pedersen O, Hjollund $\mathrm{E}$ (1982) Insulin receptor binding to fat and blood cells and insulin action in fat cells from insulin-dependent diabetics. Diabetes 31: 706-715

2. Bearn A, Billing A, Sherlock S (1951) Hepatic glucose output and hepatic insulin sensitivity in diabetes mellitus. Lancet 2: 698-701

3. Brown M, Tompkins C, Juul S, Sönksen P (1978) Mechanism of action of insulin in diabetic patients: a dose-related effect on glucose production and utilization. Br Med J 1: 1239-1242

4. DeFronzo R, Hendler R, Simonson D (1982) Insulin resistance is a prominent feature of insulin-dependent diabetes. Diabetes 31 : 795-801

5. Nosadini R, Del Prato S, Tiengo A, Duner E, Toffolo G, Cobelli C, Faronato P, Moghetti P, Muggeo M (1982) Insulin sensitivity, binding and kinetics in pancreatogenic and Type 1 diabetes. Diabetes 31: 346-355

6. Harano Y, Hidaka H, Takatsuki K, Ohgaku S, Haneda M, Motoi S, Karagoe K, Shigeta Y, Abe H (1978) Glucose, insulin, and somatostatin infusion for the determination of insulin sensitivity in vivo. Metabolism 27 (Suppl 1): 1449-1452

7. DeFronzo R, Simonson D, Ferrannini E (1982) Hepatic and peripheral insulin resistance: a common feature of Type 2 (non-insulin-dependent) and Type 1 (insulin-dependent) diabetes mellitus. Diabetologia 23: 313-319

8. Del Prato S, Nosadini R, Tiengo A, Tessari P, Avogaro A, Trevian R, Valerio A, Muggeo M, Cobelli C, Toffolo G (1983) Insulin-mediated glucose disposal in Type 1 diabetes: evidence for insulin response. J Clin Endocrinol Metab 57:904-910

9. Hall S, Saunders J, Sönksen P (1979) Glucose and free fatty acid turnover in normal subjects and in diabetic patients before and after insulin treatment. Diabetologia 16:297-306

10. Ginsberg H (1977) Investigation of insulin sensitivity in treated subjects with ketosis-prone diabetes mellitus. Diabetes 26: $278-283$

11. Nankervis A, Proietto J, Aitken P, Harewood M, Alford F (1982) Differential effects of insulin therapy on hepatic and peripheral insulin sensitivity in Type 2 (non-insulin-dependent) diabetes. Diabetologia 23: 320-325

12. Altszuler N, Bardai A, Bjerkes C, Gottlieb B, Steele R (1975) Glucose turnover values in the dog obtained with various species of labelled glucose. Am J Physiol 229: 1662-1667

13. Proietto J, Alford F, Dudley F (1980) The mechanism of carbohydrate intolerance of cirrhosis. J Clin Endocrinol Metab 51: 1030-1035

14. Albano J, Ekins R, Maritz G, Turner R (1972) A sensitive precise radioimmunoassay of serum insulin relying on charcoal separation of bound and free hormone moieties. Acta Endocrinol (Copenh) 70:487-509.

15. Alford F, Bloom S, Nabarro J (1977) Glucagon levels in normal and diabetic subjects: use of a specific immunoabsorbent for glucagon radioimmunosassay. Diabetologia 13:1-6 
16. Carruthers M, Young D (1973) Free fatty acid estimation by a semi-automated fluorimetric method. Clin Chim Acta 49: 341-343

17. Williamson D, Mallanby J, Krebs H (1962) Enzymic determination of $\mathrm{D}(-)-\beta$-hydroxybutyric acid and acetoacetic acid in blood. Biochem J 82: 190-196

18. Heding $L$ (1975) Radioimmunological determination of human Cpeptide in serum. Diabetologia 11: 541-548

19. Gambhir K, Archer J, Carter L (1977) Insulin radioreceptor assay for human erythrocytes. Clin Chem 23:1590-1595

20. Steele $R$ (1959) Influences of glucose loading and injected insulin on hepatic glucose output. Ann NY Acad Sci 82: 420-430

21. Rigg DA (1963) The mathematical approach to physiological problems. Williams \& Wilkins, Baltimore, pp 913-929

22. Best J, Taborsky G, Halter J, Porte D (1981) Glucose disposal is not proportional to plasma glucose level in man. Diabetes 30: $847-850$

23. Gottesman I, Mandarino L, Gerich J (1984) Use of glucose uptake and glucose clearance for the evaluation of insulin action in vivo. Diabetes 33: 184-191

24. Prioetto J, Harewood M, Aitken P, Nankervis A, Caruso G, Alford $F$ (1982) Validation of a practical in vivo insulin dose-response curve in man. Metabolism 31: 354-360

25. Proietto J, Nankervis A, Aitken P, Caruso G, Harewood M, Alford $F(1983)$ The physiologic action of insulin on glucose uptake and its relevance to the interpretation of the metabolic clearance rate of glucose. Metabolism 32: 1022-1028

26. Proietto J, Nankervis A, Aitken P, Caruso G, Alford F (1983) Glucose utilization in Type 1 (insulin-dependent) diabetes: evidence for a defect not reversible by acute elevations of insulin. Diabetologia 25: 331-335

27. Reaven G, Olefsky J (1978) The role of insulin resistance in the pathogenesis of diabetes mellitus. Adv Metab Disord 9: 313-331

28. Soskin S, Levine R (1937) A relationship between the blood sugar level and the rate of sugar utilization, affecting the theories of diabetes. Am J Physiol 120: 761-770

29. Reaven G, Silvers A, Farquhar J (1970) Study of the relationship between plasma insulin concentration and efficiency of glucose uptake in normal and mildly diabetic subjects. Diabetes 19: $571-578$

30. Davis B, Bernstein R, Kolterman O, Olefsky J, Reaven G (1978) Defect in glucose removal in nonketotic diabetic patients with fasting hyperglycaemia. Diabetes $28: 32-35$

31. Scarlett JA, Gray RS, Griffin J, Olefsky JM, Kolterman OG (1982) Insulin treatment reverses the insulin resistance of Type II diabetes mellitus. Diabetes Care 5: 353-363

32. Randle P, Carland P, Hales C, Newsholm E, Denton R, Pogson C (1966) Interactions of metabolism and the physiological role of insulin. Recent Prog Horm Res 22: 1-48

33. Cryer P, Silverberg A, Santiago J, Shah S (1978) Plasma catecholamines in diabetes. The syndromes of hypoadrenergic and hyperadrenergic postural hypotension. Am J Med 64: 407-412

34. Spanheimer RG, Bar RS, Ginsberg BH, Peacock ML, Martino I (1982) Comparison of insulin binding to cells of fed and fasted obese patients: results in erythrocytes and monocytes. J Clin Endocrinol Metab 54: 40-44

35. Olefsky JM (1976) Decreased insulin binding to adipocytes and circulating monocytes from obese subjects. J Clin Invest 57: $1165-1172$

36. Karnieli E, Hissin P, Simpson I, Salans L, Cushman S (1981) A possible mechanism of insulin resistance in the rat adipose cell in streptozotocin-induced diabetes mellitus. Depletion of intracellular glucose transport systems. J Clin Invest 68: 811-814

37. Kobayashi M, Olefsky J (1979) Effects of streptozotocin-induced diabetes on insulin binding, glucose transport and intracellular glucose metabolism in isolated rat adipocytes. Diabetes 28: 87-98

Received: 5 October 1983

and in revised form: 16 July 1984

Dr. A. Nankervis

Department of Medicine

University of Melbourne

Royal Melbourne Hospital

Victoria 3050

Australia 